\title{
Doing Business in Pakistan Environmental Factors and SWOT
}

\section{Analysis}

\author{
Khalid Mehtabdin, Celeste Hebert, Kurt Pahl, Jason Waite, Andrew Kochian \\ The College of Saint Rose, Albany, USA
}

\begin{abstract}
A summary of the environment faced by an organization must considering the possibility of conducting operations in the country of Pakistan. The study includes risks and opportunities found from both an economic, political, and cultural perspective. Doing business in Pakistan has become a risky endeavour because of environmental factors, which are due to the geopolitical situation around the region. What we have discovered through our SWOT analysis is that Pakistan's business sector has many threats and opportunities, and the hostility in the region is perhaps the greatest threat to both the country and its ability to conduct business in a stable way. The hostile environment, coupled with strained ties with America and other nations, such as India, will make business in Pakistan a difficult ordeal. If Pakistan wants to create growth opportunities in the business sector, it has to cease the support of terrorists, make peace with India, and enhance their political standing as a democratic state to create opportunities for entrepreneurs. Education has to be given the utmost priority in order to create these entrepreneurs for the business sector.
\end{abstract}

Keywords: doing business in Pakistan, environmental factors for business prospects in Pakistan, SWOT analysis, assessing risk of doing business in Pakistan

\section{Introduction}

Borne of a desire to provide a homeland for Muslims of the former British Raj, Pakistan is a nation of contrasts. It has been ruled both democratically and autocratically, on and off, for decades. Its economy is stable and improving, yet suffers from corruption and high inflation. Its military wages a formal war against terrorists in remote areas while being accused of aiding those very same terrorists. An anti-American feeling has swept the country despite constant acceptance of foreign aid from the US. In many ways, its infrastructure is superior to some of its larger neighbors, yet it cannot provide electricity to its citizens on a regular basis. It relies heavily on agriculture, thanks to its large irrigation system, but that system has been betrayed by two consecutive years of devastating floods. It possesses one of the world's largest labor forces, though it is estimated a majority of that workforce cannot read. The government is technically secular, yet the Islamic religion plays a critical role in its culture.

Khalid Mehtabdin, Ph.D., Professor of Economics, Department of Economics, The College of Saint Rose.

Celeste Hebert, MBA, School of Business, The College of Saint Rose.

Kurt Pahl, MBA, School of Business, The College of Saint Rose.

Jason Waite, MBA, School of Business, The College of Saint Rose.

Andrew Kochian, MS, School of Business, The College of Saint Rose.

Correspondence concerning this article should be addressed to Khalid Mehtabdin, Department of Economics, The College of Saint Rose, Albany, N.Y., 12203, USA. E-mail: mehtabdk@strose.edu. 
It is within this framework that a venture looking to conduct business in Pakistan must consider both the opportunities and the pitfalls. In its most recent survey, the World Bank ranked Pakistan only the 105th of 183 economies for doing business. Most challenges relate to civic needs and requirements, such as paying taxes, registering property, enforcing contracts and, as mentioned, getting electricity. On the other hand, an enterprising organization might be able to profit from a populace thirsty for employment and the spoils of a growing economy.

The following study of Pakistani society looks at the current state of the country's economy and its political picture. We also take a look at the overall strengths, weaknesses, opportunities, and threats a business would face in Pakistan. We conclude with a look at Pakistani culture and the role of the Islamic religion. In doing so, we discovered a nation that presents significant risks to business while also providing the opportunity for considerable reward.

\section{Political Environment}

The Pakistani government is organized as a Federal Republic comprised of four provinces: Sindh, Punjab, Khyber Pakhtunkhwa, and Balochistan. Additionally, the government maintains control over one federal capital territory (Islamabad), a group of tribal areas, and de facto control over the western-most piece of the disputed Kashmir region. The legislative branch of government includes a 342 member National Assembly and a 100 member Senate. The executive branch is administered by a President (acting as the Head of State and Commander in Chief of the military) and a Prime Minister (acting as the Head of Government). The judicial branch of Pakistan is headed by a Supreme Court (Central Intelligence Agency, 2011).

Since its inception in August 1947, Pakistan has experienced periods of civilian control interrupted by alternating periods of military rule. The constitution of the country has been suspended, or martial law declared, at least three times in the last 40 years (Central Intelligence Agency, 2011). Most recently, the constitution, having been restored in pieces during 2002 by General Pervez Musharraf, was once again suspended in November, 2007, when Mr. Musharraf was unable to reach a power sharing arrangement with past political rivals Nawaz Sharif and Benazir Bhutto, both former prime ministers. Though the constitution was restored the following month, Ms. Bhutto was assassinated less than two weeks later. In elections held in February, 2008, Mr. Musharraf's party was defeated and Ms. Bhutto's widower, Asif Ali Zardari was elected President. An arrest warrant was later issued accusing Mr. Musharraf of having a connection to the murder, though he remains in exile to date (Reuters, 2011).

During his time in power, Mr. Zardari has faced several political crises, both domestically and internationally. Pakistan has gained a reputation throughout the world as a safe-haven for terrorist organizations and unable to control rogue elements that operate within its borders. For example, throughout much of the last decade, the Taliban has begun to increase its influence, particularly in the northern regions of the country, such as the Swat valley. The Taliban looked to impose Islamic law in the areas in which it controlled, and the secular Pakistani government relented in February, 2009 (Khan, 2009). Later that year, as the Taliban took control of land close to the national capital, the Pakistani military began a campaign to take back control of the area.

The military's campaign against the Taliban remains an open issue as the Taliban is also supported by other groups, such as Al Qaeda and the Haqqani network. The Haqqani's, in particular, are a family run organization residing primarily in North Waziristan. The group fights along the Pakistan-Afghanistan border and, according to the New York Times, fears eventual control of the Pashtun region between the two countries 
(Shah \& Gall, 2011). For this reason, it is speculated that the Pakistani military shares the same goal and, thus, presents little opposition to the group, if not aiding them outright (Shah \& Gall, 2011).

The United States, on the other hand, in a proxy role for the Afghan government, has requested that aid to the Haqqani network be eliminated. The Haqqani situation is one example of a series of irritants to an uneasy working relationship between the US and Pakistan, created following the September 11th attacks. Since 2001, the US has sought Pakistani help in apprehending those individuals or organizations thought to be involved in the attacks or connected to those organizations, for example, Osama Bin Laden. In return, Pakistan has received millions of dollars in aid for both military and civilian purposes. At times though, the United States has pushed Pakistan to be more forceful with its military campaign and has even run military operations in Pakistani territory without Pakistani permission. The raid to capture Bin Laden was one such operation. In return, the Pakistani government has expelled military trainers from its land, prompting the US to suspend some of the aforementioned aid (Schmitt \& Perlez, 2011).

Meanwhile, Pakistan's political relations with India remain difficult to improve. Ever since both countries became independent of British control in 1947, they have claimed and fought over the Kashmir territory located near Pakistan's northern region. This has led to armed conflict between the two countries and, for three days in November, 2008, a series of terror attacks swept the Indian city of Mumbai. Though Pakistan arrested seven individuals thought to be behind the attacks, India remained unconvinced as the leader of the group that carried out the attacks was not included among the arrests (Masood, 2009).

For an organization considering doing business in Pakistan, continual political instability means an investment in the country must be considered risky. On the one hand, the country is operating under a democratic system and the constitution remains in place. The Pakistani military continues to confront some of the paramilitary organizations operating there and continues to received aid and training from the US, despite recent setbacks. On the other hand, Pakistan has experienced similar episodes in the past, only to see autocratic rule take place when circumstances allowed.

\section{Economic Environment}

Despite repeated bouts with political instability, the Pakistani economy has been stable, if not growing, for much of the past decade. Poverty decreased by as much as 10\% between 2001 and 2007 and GDP grew between 5\% and 8\% from 2004 to 2007 (Central Intelligence Agency, 2011). However, several events have served to stress the economy in recent years, forcing the government to re-allocate resources and slowing growth in all sectors.

According to the Pakistani government, the basis for the economy is agricultural with major crops including wheat, cotton, rice, and sugar cane and major industries that include textiles and chemicals (Government of Pakistan, n.d.). The services sector comprises 54.6\% of the economy, with agriculture and industry roughly splitting the remainder. Gross domestic product stands at $\$ 464.9$ billion with an estimated 2010 growth rate of 4.8\%, an improvement of 3.2 points since 2008 (Central Intelligence Agency, 2011).

In October, 2005, a destructive 7.6 magnitude earthquake struck Pakistan and was centered in the Kashmir region. By one estimate, damages to farming and related infrastructure totaled $\$ 440$ million ("US Agency", 2005). This natural disaster was a setback for an economy that had previously been growing at a steady pace due, in part, to fiscal reforms that earned the country a global top 10 ranking in 2005 for reform by the World Bank (“Doing Business in 2006”, 2005). Despite the impact, support from around the world helped to put 
Pakistan back on a sustainable path.

Increasing oil and food prices provided the impetus for Pakistan's current account deficit to balloon 74\% from 2007 to 2008 (“Q+A-Pakistan”, 2008). By the end of the third quarter of that year, Pakistan did not have enough currency reserves on hand to cover the country's imports, resulting in a balance of payments crisis. Only seven months in office, President Zardari agreed to a standby arrangement with the International Monetary Fund, helping to ease the crisis. By 2009, lower oil prices helped to stabilize currency reserves and the current account improved. More recently, in 2010, the current account had improved to a surplus of almost $\$ 748$ million and currency reserves reached an all-time high of \$17.1 billion in April, 2011 (Ministry of Finance, n.d.).

Another natural disaster struck the country in 2010 as severe floods deluged the Indus River basin due to an unprecedented monsoon season. According to the Pakistani Ministry of Finance, the floods reduced economic growth by two points in addition to $\$ 10$ billion in infrastructure damage. Crop yields were negatively impacted, suffering negative growth of 4\%. Manufacturing growth was near zero as well. 2011 witnessed another round of flooding and, according to the BBC News, three million citizens require aid and 800,000 are still displaced as of November (Agencies Warn, 2011).

In light of the many pressures faced by the Pakistani people, the economy has remained relatively stable. Though oil prices increased in the past year, GDP growth rate still improved 2.4\% from 2010 to 2011 (Ministry of Finance, n.d.). Inflation remains the country's greatest concern, rising from $7.7 \%$ in 2007 to more than $13 \%$ in 2010 (Central Intelligence Agency, 2011). Escalating food and fuel prices resulting from flood-driven shortages have only served to exasperate the problem. If the government cannot solve this immediate problem, the economy will have difficulty in maintaining its resilient growth rate.

\section{Technological Environment}

If one issue dominates any discussion of technology in Pakistan, it is the amount of electricity, or lack thereof. As the economy has improved over time, demand for electrical appliances has increased and the corresponding demand for electricity has also increased. In the meantime, supply has not kept up with demand. The cash strapped government has diverted resources that could be used for new power supplies to other areas such as flood relief and the ever-existent conflicts on Pakistan's borders. The floods, in particular, caused as much as $\$ 125$ million in damages to the power sector alone, according to the New York Times (Gall, 2010). To cope with the lack of supply, power producers routinely implement rolling outages across the country for as much as 22 hours per day (S.S., 2011). The supply/demand conundrum becomes particularly problematic during the summer months when temperatures can reach 100 degrees. This has led to protests throughout the country, conflicts with police, and damage to government buildings (Pakistan’s Energy, 2011).

The lack of electricity has a drag effect on the overall economy. Pakistan's textile industry has been especially impacted by the blackouts. Plants must cope with constant shutdowns. For example, the lack of productivity has led to 200 plant closures and layoffs of $10 \%$ of the textile workforce in Faisalabad alone, Pakistan’s third largest city (Rodriguez, 2011). Plans are underway to build a new $\$ 12$ billion plant in northern Pakistan, but the plant would be located in disputed territory and funding for its construction has not yet been secured (S.S., 2011). As a result, the World Bank ranks Pakistan 166 in the world (out of 183 economies) for “Getting Electricity” (Doing Business, 2012). 


\section{Business Environment}

\section{Strengths}

Abundant natural resources are one of Pakistan's many strengths. The main natural resources of Pakistan include arable land, water, and natural gas reserves. Currently, 28\% of Pakistan's land is under cultivation and is kept hydrated by the world's largest irrigation system. Agriculture alone accounts for $21 \%$ of Pakistan's GDP and employs roughly $42 \%$ of the labor force. Cotton, wheat, rice, sugarcane, fruits, and vegetables are the main crops produced and make up nearly $75 \%$ of the value to total crop output (Retrieved from http://state.gov). In addition to crops, Pakistan is home to the worlds second largest salt mine, fifth largest gold mine, fifth largest coal reserves, and seventh largest copper mine (Retrieved from http://potentialofpakistan.com).

A large consumer market is one of Pakistan's greatest strengths. With a population in excess of 180 million people, Pakistan is considered to have the world's 9th largest consumer market. Pakistan is generally made up of three large consumer markets-Karachi, Lahore, and Faisalabad —all operating somewhat autonomously. In addition to large numbers of people, the dispersion of the population is becoming more concentrated in cities. With a blooming economy, many of these individuals have increased their standard of living and income substantially, giving them more spending ability. This can be a great asset to businesses inside Pakistan as the growth of the population accompanied by a higher standard of living has the ability to sustain substantial business growth.

In addition to a large consumer market, Pakistan also has a well trained competent workforce. According to the CIA World Factbook, the total number of Pakistan's labor force is 55.8 million people, making it the 9th largest workforce. Not only does Pakistan have a large labor force, but as the economy grows and the standard of living rises, many Pakistanis have better access to education. The combination of a large educated workforce is a great asset to business in Pakistan and abroad. Businesses need to tap into this great reserve of talent.

Pakistan's geographic location is also a great asset in their ability to do business. Pakistan could be considered a business corridor linking the Middle-East, China, Iran, Afghanistan, the Central Asian Countries, and Asia Pacific (Retrieved from http://www.brecorder.com). This strategic location makes Pakistan a viable business partner in the region.

A relatively free media is another strength in Pakistan's ability to do business. Although there are political pressures that often result in government bans, for the most part, the Pakistan media enjoys a wide range of freedom of expression. There are over 40 television channels that show programs ranging from soaps to political commentary. Radio is also considered as an integral part of the information stream, especially in rural areas where television is often not available.

\section{Weaknesses}

Government, military, and business corruption has long plagued Pakistan. In 2006, the Corruption Perception Index (CPI) ranked Pakistan at 142 out of the 163 countries considered. The CPI ranks countries from least to most corrupt. In 2004, Pakistan was ranked 129 out of 145 countries. The extent of corruption has had a dramatic effect on business in Pakistan. Bribes and kickbacks are the most common costs to business. The indirect costs are much more severe. High illiteracy rates have also hampered Pakistan's ability to conduct business (Pakistan Country Profile, 2006). Although the literacy rate is rising, it is estimated that 54\% of Pakistanis remain illiterate. It is estimated that a whopping $74 \%$ of females remain illiterate. Although the government has instituted several programs to promote literacy, none have been successful to date. This high 
illiteracy rate certainly hampers business in Pakistan as companies move to other parts of the world with higher literacy rates.

Electricity shortages continue to be a debilitating problem in Pakistan. An inadequate distribution infrastructure has resulted in massive power shortages that have severely hampered manufacturing activities

\section{Opportunities}

Pakistan has recently been held as a country where it's quite easy to do business. The World Bank rated Pakistan as the second best country in Asia Pacific in terms of "ease to do business". Pakistan's FDI laws, tax policies, foreign exchange liberalization, and banking procedures make it friendly and non-cumbersome to do business in Pakistan (Retrieved from http://www.brecorder.com).

Trade initiatives currently underway through USAID are another opportunity that Pakistan has the ability to capitalize on. Among these initiatives is the creation of an electronic trade portal providing the government, Pakistani exporters, and international buyer's access business information in real time. It is hoped that this atmosphere will spur economic development and business creation within Pakistan. This portal is expected to be user friendly, promote businessmen, and enhance the quality of existing businesses. The portal will replace other activities and promote business in a more effective manner (Retrieved from http://www.Dawn.com).

The growth of the Halal food market is yet another opportunity for Pakistan. Halal means "permissible" for Muslim consumption. Halal products have begun to move into mainstream businesses as their demand has steadily increased. As a Muslim country, Pakistan is positioned to be a leader in the world Halal food market. The demand for Halal food has drastically increased throughout the U.S., Canada, Europe, the Middle East, Southeast Asia, North Africa, and Australia. The current Halal food market was valued at \$635 billion in 2010 and comprises approximately $16 \%$ of the global food industry. Many non-Muslims have been attracted to Halal food because of the strict safety and sanitation rules. In addition, many ethnic stores and restaurants have sprung up in metropolitan areas around the world. With Pakistan's agricultural and food processing ability, this may be an area where they can thrive (Retrieved from http://halalfocus.com).

The growth of Islamic banking is another opportunity that Pakistan should not let slip by. Currently, the Islamic banking share in Pakistan is only at 8\%. However, there is a fast growing trend that Pakistanis are trying to be financially successful while remaining religiously correct. The global financial crisis has only helped to spur the popularity of Islamic banking. The financial crisis, combined with Pakistan's ability to expand Islamic banking is a great opportunity for Pakistan's business sector.

\section{Threats}

Inflation is expected to remain high for the next several months as the massive flooding in 2010 destroyed an estimated $10 \%-15 \%$ of Pakistani farmland and devastated grain storage facilities, putting further pressure on supplies. Inflation is expected to rise at a rate of $11.7 \%$ in 2011 as a result of increasing commodity prices, the depreciation of the Rupee against the Dollar, and rising prices of fuel (Pakistan, 2011).

The long standing war with India has been, and continues to be, a serious threat to business in Pakistan. The dispute over Kashmir continues to plague the region. The periodic eruption of violence has long hampered the stability of the area. The constant threat of conflict between the two nations utilizes a great deal of Pakistan's resources, further damaging their ability to grow business.

Political target killings are another great threat to Pakistan's ability to attract business. The killings mainly take place in the city of Karachi where unknown gunmen fired indiscriminately throughout several 
neighborhoods. In total, more than 300 people were killed in July alone. Typically, the target killings are politically motivated and carried out against political workers or those affiliated with political parties. The recent indiscriminate killings have severely hampered Pakistan's ability to do business as the raids reflect the poor security that is present throughout the region.

Pakistan's affiliation with the Taliban continues to be a threat to business. Recently, Pakistan decided to enter into peace talks with the Taliban instead of fighting them as the U.S. had hoped. The government now appears less willing to challenge insurgent groups, instead deciding to make peace with them. This has placed even greater strain on Pakistan's already fragile relationship with the U.S., and the majority of world powers. This additional strain is likely to further threaten Pakistan's ability to attract new business (Retrieved from http://washingtonpost.com).

\section{Regulatory Environment}

The Securities and Exchange Commission of Pakistan (SECP) is the regulatory body for Pakistan. In October 2011 SECP registered 257 new companies, of which 244 were private companies, 11 were single member companies, a not-for-profit association and the United Kingdom as a foreign company. The new companies incorporated in the following sectors: trading, information technology, services, transportation, Hajji and Umrah services, food and beverage, construction, power generation, textile, pharmaceutical, agricultural farming, education, chemical, tourism, fuel, energy, and communication. The breakdown of the new 257 by region: 85 registered in Lahore, 82 registered in Karachi, 61 registered in Islamabad, 12 registered in Peshawar, eight registered in Multan, seven registered in Faisalabad, and two registered in Quetta (SECP Registers, 2011).

Also in the month of October, 2011, the SECP finalized the revised draft code of corporate governance. The code does not allow the same person to be CEO and Chairman of the board of directors. The revision was finalized between the SECP and the task force of Pakistan Institute of Corporate Governance and will be implemented in November 2011. The code will be implemented by the stock exchanges who are the front line regulators of listed companies. An official of the SECP said "the upgraded code is needed to safeguard the rights of shareholders by improving the disclosures and define responsibilities of directors, CEO, and the chairperson of the board". This revised code has also incorporated more strict conditions to being a member of the board for a company. The goal is to further improve to be close to the International standards (A Reporter, 2011).

\section{Cultural Environment}

The definition of culture can be easily defined as human response to nature and history (Government of Pakistan, n.d.). Pakistan has been a melting pot of nationalities that have influenced their cultural environment. The current ethnic groups to inhabit Pakistan are Punjabi, Pashtun (Pathan), Sindhi, Sariaki, Muhajirs, and Balochi. The main religions are 95\% Muslim (Sunni 75\% and Shia 20\%) and other religions like Christianity and Hindu make up the remaining 5\% (Central Intelligence Agency, 2011). The estimated population is 135 million. The tribal areas are: The Chitral Valley, Swat Valley, Hunza Valley, and Kaghan Valley. The Chitral Valley is comprised of mostly Muslims and Kafir-Kalash, a pagan tribe. The Swat Valley was the cradle of Buddhism; residents claim to be descendants of Alexander the Great. The Hunza Valley people are Muslim and known for longevity because of their diet and way of life. The Kaghan Valley people are Muslim-Pathans and Kohistanias and Gujars. The inhabitants of each region of Pakistan are known for their tribal clothing, which 
are unique to each area (Pakistan, 2011).

Food is a large part of the culture in Pakistan. With 95\% of the population being Muslim there are only two food customs that are allowed, no pork and fasting during Ramadan. Two components of Pakistani recipes are spices and curry. Marinating meat in yogurt is also typical in a Pakistani recipe. The food in the southern regions of Pakistan are said to be more exotic and highly spiced. The unique flavor of Pakistani food is attributed to the use of pickles, chutneys, preserves, and sauces paired with curried meats, seafood, vegetables and lentils. Wheat and flour are main ingredients in the daily diet. The food custom of sacrificing an animal happens on the last month of the Muslim calendar and is called Eid-ul-Azha (Feast of Sacrifice). The custom is to divide the meat into three portions and donate some to the poor, relatives and/or friends and the third part is for the home of the person who made the sacrifice. Food is also part of the Ramadan fasting period. Food is used in the celebration of a new birth, and a child turning six or seven months (Pakistan, 2011).

Marriage in the Muslim tradition is roughly a four day process. It starts with the bride being secluded in an area of the house called a mayun or lagan. The day before, a ceremony called menhdi is held, where the bride has her hands and feet covered in henna. Before the ceremony, a prayer for successes is said and, after, the guests are given dried dates. Before the marriage can be official, both the bride and the groom must sign a formal legal document with witnesses present, called nikah (Pakistan, 2011).

The rituals of the Muslim religion are a vital part of daily life. Ramadan requires fasting from sunrise to sunset. Also during this time, Muslims are required to help the less fortunate with gifts of food and money. The end of Ramadan starts with an elaborate breakfast followed by prayer. Of equal importance is the celebration of the birth of Muhammad, called Eid-I-Milad-un-Nabi, which is the 3rd month of the Muslim calendar. The Festival Shab-I-Barat is in the 8th month of the Muslim calendar. It is considered the day where lives and fortunes are registered in heaven for the coming year. Muharram is another ritual of the Muslim culture (Pakistan, 2011).

The most important feature relating to Muslim culture was the development of cities and trading. The development of the mosque holds value as a religious place and also to hold commercial and social gatherings. This bond between Islam and Pakistan was strengthened by the Sufis, saints, and scholars. The Sufis imprinted their message of the Prophet of Islam upon the Pakistani culture through their intellectual content (Government of Pakistan, n.d., p. 6).

Around the 19th century, Pakistan was occupied by the British. During this time, settlements of canal colonies were established, along with railways, for communication, defense, and commercial considerations. The British introduced their language as well as new educational and administrative systems. The introduction of their language brought about the Western style of living and culture to Pakistan. For instance, the British introduced the game of Cricket which has become an integral part of Pakistani culture to the present day (Government of Pakistan, n.d., p. 7).

The government of Pakistan created The Cultural Policy of Pakistan to highlight the past and provide guidelines for the future. The purpose is to keep the heritage of the culture in view and provide an environment for growth and promotion of the Constitution of the Islamic Republic of Pakistan. The first 10 points in the objective of The Cultural Policy are as follows:

(1) To wake the spirit of participation of the people of Pakistan and to safeguard their rights in promotion of culture;

(2) Relate spiritual aspects of the culture to the physical manifestations and to highlight and develop the 
values of belief system;

(3) Map, record, and document all cultural assets in the country and national cultural strategies to maintain cultural heritage;

(4) Meet globalization challenges through enhanced awareness using traditional and modern technology means of cultural heritage through expressions in the arts;

(5) Enrich the national language by making it truly representative by promoting historical and existing Pakistani languages;

(6) Application of modern technology to current social and economic needs through the use of critical thinking and reasoning;

(7) Encourage growth of public/private partnerships and support civil society cultural incentives;

(8) Provide free and healthy environments for promoting all cultural activities;

(9) Encourage thoughts and aspirations of all that relate to cultural activates toward the process of national integration;

(10) Highlight cultural tolerance, harmony and social integration in the cultural fabric and eradicate violence and intolerance by affirmative cultural action using education and legislation (Government of Pakistan, n.d., pp. 12-13).

Also noted in the guidelines of the policy are that laws will be created at the national and provincial levels to discourage intolerance, racial fanaticism, and violence. Laws that limit culture growth will be repealed to ensure freedom of expression and national identity. This policy was formed to keep the best interests of the nation in view. It aims to maintain the preservation of the heritage and culture of Pakistan through the ever-changing world. Keeping the link between past and present will empower the nation to hold onto its identity and secure a bright future (Government of Pakistan, n.d., pp. 1-7).

\section{Environmental Policy}

The National Environmental Policy is to provide a framework for the environmental issues Pakistan is facing-pollution of fresh water and coastal waters, air pollution, lack of proper waste management, deforestation, desertification, and climate change. The goal of the Environmental Policy of Pakistan is to protect, conserve, and restore the environment and to improve the quality of life through sustainable development. The objectives listed in the policy are: (1) conserve, restore, and manage environmental recourses; (2) integration of environmental issues within policy making and planning processes; (3) better environmental management through building governmental agencies and other stakeholders; (4) meeting international obligation in conjunction with national aspiration; and (5) creating demand for environment using mass awareness and community mobilization (Government of Pakistan, 2005, p. 9).

To improve the environment within Pakistan, the government would need to be involved. For the water supply and management of the water resources, the government may: develop legal and policy frameworks to promote safe drinking water for Pakistan; increase the coverage of the water treatment facilities and water supply; establish quality monitoring and surveillance systems; promote technologies to harvest rain water in rural an urban areas; enact a Water Conservation Act to foster water conservation; and launch phased programs to clean up the quality of the water bodies (Government of Pakistan, 2005, p. 10).

Pollution caused by liquid and solid waste could be reduced and prevented through the following possible government involvement: enforcing the National Environmental Quality Standards and Self-Monitoring and 
Reporting System; introducing a discharge licensing system; making the installation of wastewater treatment plants a part of all sewer schemes; developing and implementing a National Sanitation Policy; establishing cleaner production centers and promoting cleaner production practices and techniques; developing and implementing proper water treatment for municipal, industrial, hazardous, and hospitals; launching a National Oil Spill Contingency Pan; and establishing a Marine Pollution Control Commission (Government of Pakistan, 2005, p. 11).

\section{Conclusions}

As we have discovered throughout our investigation, Pakistan's business sector has many threats and opportunities. The hostility in the region is perhaps the greatest threat to both the citizens of Pakistan and their ability to conduct business. This hostile environment, coupled with waning ties with the U.S. and other nations will make business in Pakistan to be a difficult ordeal. However, if Pakistani officials are able to reign in the warring factions, cease support of terrorists, make peace with their neighbors, and enhance their political standing, there are a great many business opportunities to be had. Through enhancing their education systems they can increase literacy rates, further attracting foreign businesses looking to expand in the emerging markets of Pakistan. The world economic crisis further solidifies Pakistan's ability for growth. As many countries and businesses are suffering economically, they are looking for ways to enhance productivity while cutting costs. Given Pakistan's current situation, and their ability for growth, the country remains an attractive location for business ventures.

\section{References}

A Reporter. (2011). Revised draft code of corporate governance. Retrieved from http://www.dawn.com/2011/11/01/revised-draft-code-of-corporate-governance.html

Agencies warn of acute Pakistan floods relief shortfall. (2011). BBC news. Retrieved from http://www.bbc.co.uk/news/world-asia-15643468

Central Intelligence Agency. (2011). The world Factbook: Pakistan. Retrieved from https://www.cia.gov/library/publications/the-world-factbook/geos/pk.html

Doing Business in 2006: South Asian Countries Pick up Reform Pace, says World Bank Group; India Ranks 116th, 25 Places After China; Pakistan Among Top 10 Reformers. (2005). The world book online. Retrieved from http://web.worldbank.org/WBSITE/EXTERNAL/COUNTRIES/SOUTHASIAEXT/0\%2C\%2CcontentMDK:20643510 men uPK:158937 pagePK:146736 piPK:146830 theSitePK:223547\%2C00.html

Doing Business in Pakistan. (2012). World bank group. Retrieved from http://doingbusiness.org/data/exploreeconomies/pakistan Economist Intelligence Unit. (2011). Country Report: Pakistan. Retrieved from http://country.eiu.com/Pakistan

Gall, C. (2010). Pakistan flood sets back infrastructure by years. Retrieved from http://www.nytimes.com/2010/08/27/world/asia/27flood.html?scp=1\&sq=Pakistan\%20Flood\%20Sets\%20Back\&st=cse

Government of Pakistan. (2005). National environmental policy: Ministry of environment. Retrieved from http://www.environment.gov.pk/nep/policy.pdf

Government of Pakistan. (n.d.). About Pakistan. Retrieved from http://pakistan.gov.pk/

Government of Pakistan. (n.d.). The cultural policy of Pakistan: Ministry of culture. Retrieved from http://www.culturelink.or.kr/ASP/Board/FileDownLoad.asp?IDX=441

Khan, I. (2009). Pakistan agrees to enforce Islamic law in violent region. Retrieved from http://www.nytimes.com/2009/02/17/world/asia/17shariah.html?scp=1\&sq=Pakistan\%20Agrees\%20to\%20Enforce\%20Islam ic\%20Law\%20in\%20Violent\%20Region\&st=cse

Masood, S. (2009). Pakistan to charge 7 in Mumbai attacks. Retrieved from http://www.nytimes.com/2009/09/20/world/asia/20pstan.html 
Ministry of Finance. (n.d.). Overview of the economy: Pakistan economic survey 2010-2011. Retrieved from http://www.finance.gov.pk/survey/chapter_11/Overview\%20of\%20the\%20Economy.pdf

Pakistan. (2011). Culture of Pakistan. Retrieved from http://www.everyculture.com/No-Sa/Pakistan.html

Pakistan's Energy Shortage Lights out Another Threat to a Fragile Country’s Stability. (2011). The economist. Retrieved from http://www.economist.com/node/21531495

Q+A-Pakistan Weighs Options As Payments Crisis Looms. (2008). Retrieved from http://www.forbes.com/feeds/afx/2008/11/04/afx5644548.html

Reuters. (2011). Pakistan issues arrest warrant for Musharraf in Bhutto's killing. Retrieved from http://www.nytimes.com/2011/02/13/world/asia/13pakistan.html?scp=1\&sq=Pakistan\%20Issues\%20Arrest\%20Warrant\%20f or\%20Musharraf\%20in\%20Bhutto\%E2\%80\%99s\%20Killing\&st=cse

Rodriguez, A. (2011). Pakistan power shortages keep growth prospects dim. Retrieved from http://www.articles.latimes.com/2011/aug/31/world/la-fg-pakistan-power-20110901

S.S. (2011). A new dam for Pakistan potentially electrifying. Retrieved from http://www.economist.com/blog/banyan/2011/10/new-dam-pakistan

Schmitt, E., \& Perlez, J. (2011). U.S. is deferring millions in Pakistani military aid. Retrieved from http://www.nytimes.com/2011/07/10/world/asia/10intel.html?pagewanted=all

$\begin{array}{lllllll}\text { SECP } & \text { registers } & 257 & \text { companies } & \text { (2011). } & \text { Retrieved from }\end{array}$ http://www.secp.gov.pk/news/PDF/News_11/PR_Nov05_2011.pdf

Shah, P. Z., \& Gall, C. (2011). For Pakistan, deep ties to militant network may trump U.S. pressure. Retrieved from http://www.nytimes.com/2011/11/01/world/asia/haqqani-militants-act-like-pakistans-protected-partners.html?_r=1\&scp=1\&s q=For\%20Pakistan,\%20Deep\%20Ties\%20to\%20Militant\%20Network\%20May\%20\&st=cse

The World in 2013. (2012). The economist/economist (p. 43). Retrieved from http://www.economist.com/theworldin/2013

US Agency for International Development. (2005). South Asia-Earthquake. Retrieved from http://reliefweb.int/sites/reliefweb.int/files/resources/20D7A9210A8F4D53492570BD0006FD4F-usaid-sas-17nov.pdf

Appendix A

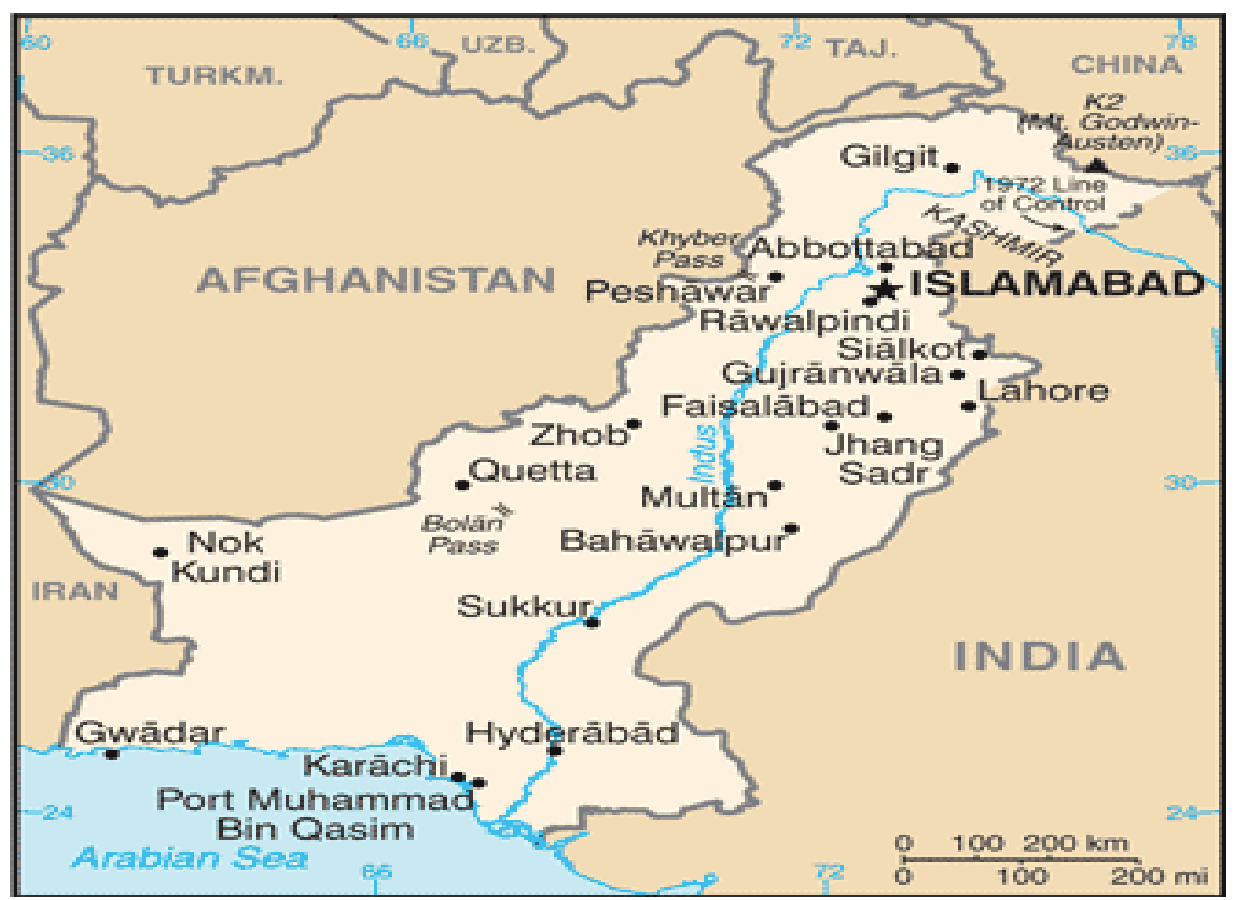

Figure A1. Map of Pakistan 